\title{
Working Capital Management in Toolfab Engineering Industries Pvt Ltd
}

\author{
J Pavithra, Ajith, A. Kamal
}

\begin{abstract}
A very much planned and actualized working capital administration is required to contribute decidedly to the production of a company's worth. "Working Capital" is the capital put resources into various things of current resources required for the business, viz, stock, account holders, money and other current resources, for example, advances and advances to outsiders. Those present resources are basic for smooth business tasks and appropriate usage of fixed resources. The firm ought to keep up adequate degree of working cash-flow to create upto a given limit and expand the arrival on interest in fixed resources. Lack of working capital prompts lower limit usage, lower turnover and henceforth lower benefits. Working Capital, in overabundance of the sum required to deliver to full limit, is inactive and subsequently prompts decrease in benefits. Henceforth the decree "Ampleness is an ethicalness, surfeit isn' $t$ ". The examination focuses on the fundamental segments of working capital like stock administration, money due administration and money the board of Public Enterprises. The apparatuses utilized in this investigation incorporates proportion examination, pattern examination and rate strategy. [1],[3],[5] Keywords : working capital,management,capital
\end{abstract}

\section{INTRODUCTION}

In budgetary administration, two significant choices are extremely essential and urgent. They are choice with respect to fixed resources/fixed capital and choice in regards to working capital/current resources. Both are significant and a firm consistently breaks down their impact to conclusive effect upon productivity and hazard. Fixed capital alludes to the assets put resources into such fixed or perpetual resources as land, building, and apparatus and so on. Though working capital alludes to the assets secured up materials, work in advancement, completed merchandise, receivables, and money and so on. [2 ],[ 4],[6]

Along these lines, in basic words, working capital might be characterized as "capital put resources into currentassets". Here current resources are those benefits, which can be changed over into money inside a shortperiod of time and the money got is again put into these advantages. Along these lines, it is continually getting or coursing. Henceforth, working capital is otherwise called circling capital or floatingcapital. [7],[ 9], [11]

\footnotetext{
Revised Manuscript Received on July 22, 2019.

J.Pavithra, Department of MBA, Bharath Institute of Higher Education and Research, Tamilnadu, India. Email: pavithralect@yahoo.com

Ajith, Department of MBA, Bharath Institute of Higher Education and Research, Tamilnadu, India. Email: ajithmba@gmail.com

Dr.A.Kamal, Department of EEE, Bharath Institute of Higher Education and Research, Tamilnadu, India. Email: ak2-anvi@yahoo.co.in
}

Working capital assumes a significant job in the everyday exercises of a business venture. The working capital administration personally interfaces the working of each division in the business concern. On the off chance that working capital is fumbled, it might [31],[33],[32]influence the presence of the business itself. In such units the generation of money in the present resources would be high, however the business may confront the deficiency of stock. On the off chance that the blocked assets in current resources are not appropriately used at the correct time for the buy of stock, it won't just expand the benefit acquiring limit of the firm yet additionally lessen the hazard. So also, current liabilities should keep in such an extent, that present resources can be changed over into money to pay for it during the time of dissolvability emergency. [8],[ 10],[12]

\section{STATISTICAL TOOLS USED FOR PERCENTAGE}

\author{
RATIO ANALYSIS \\ FINANCIAL (or) SOLVENCY RATIO \\ - Current ratio \\ - Quick ratio \\ - Absolute ratio \\ PROFITABILITY RATIO \\ - Gross profit ratio \\ - Operating ratio \\ - Net profit ratio \\ Comparative balance sheet (2012-2016) \\ Commonsize balance sheet (2012-2016)
}

\section{DATA ANALYSIS AND INTERPRETATION}

\section{CURRENT RATIOS:}

The current ratio is the ratio of total current assets to total current liabilities. It is calculated by dividing current assets by current liabilities. A current ratio of one means that book value of current asset is exactly the same as book value of current liability. [13], [15], , 17]

Current ratios $=$ current assets $/$ current liabilities 
Table: 1 Current ratio

\begin{tabular}{|l|l|l|l|}
\hline YEAR & $\begin{array}{l}\text { CURRENT } \\
\text { ASSETS } \\
\text { (In Rs.Lakhs) }\end{array}$ & $\begin{array}{l}\text { CURRENT } \\
\text { LIABILITIES } \\
\text { (In RS.lakhs) }\end{array}$ & RATIO \\
\hline 2012 & 9.8 & 6.41 & 1.44 \\
\hline 2013 & 11.2 & 11.76 & 0.95 \\
\hline 2014 & 19.82 & 9.53 & 2.02 \\
\hline 2015 & 42.18 & 11.32 & 3.72 \\
\hline 2016 & 35.09 & 15.24 & 2.30 \\
\hline
\end{tabular}

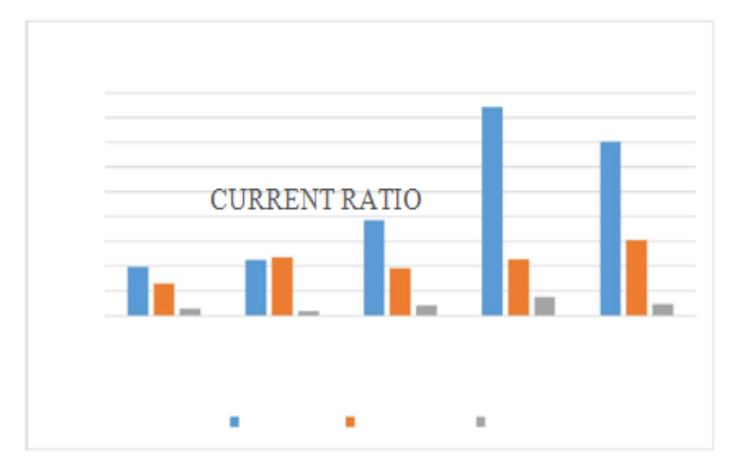

Fig:1 CHART SHOWING CURRENT RATIO

\section{RESULTS}

From the above investigation, it very well may be gotten that the working capital has grown up enormously from 0.15 to 1.15 during the examination time frame

- $\quad$ From the examination it very well may be derived the liquidity position of the firm has diminished from 4.93 to 1.23 during the year 2012 to 2015

- From the above examination it was discovered that net benefit of an organization has dropped to most reduced proportion of 4.88 in the 2016 .

- The fixed resources proportion demonstrates that the working capital of this organization is supported by long haul finances which show productive subsidizes the board. [14], [ 16], [18]

- The transient liquidity and long haul liquidity position of the worry were concentrated to assess the working capital of the worries.

\section{V.DISCUSSION}

To keep up a superior liquidity position of the organization can build it resource through better money the board.

[19],[21],[23]
- The net benefit proportion of the firm was variance during the investigation time frame it demonstrates a diminishing proportion showing and inadmissible liquidity position of the firm . [26],[28],[30]

- Profit edge of the organization ought to be increment by increment the net deals to have more benefit to the firm

- The extent of increment in the working benefit is up to the proportionate increment in the business .This demonstrates the working costs and the expense of offers are medium . It was proposed that administration ought to pursue the equivalent. [25],[27],[29]

- The money and Bank Balance of the organization is great.

\section{CONCLUSION}

The present investigation uncovers that the liquidity position of this organization is relatively great as it approaches the standard standards all through the time of study. In general, it tends to be presumed that the organization's general hazard assessment procedure isn't at wanted level and the creator has made the reasonable proposal for the improvement in operational and administrative effectiveness of the organization as to keep up and increment further by successful use and control of the considerable number of benefits. [20],[ 22], [24]

\section{REFERENCES}

1. G BharthVajan R., Ramachandran S.,Psychographic dimensions of training,2016,International Journal of Pharmacy and Technology,V-8,I-4,P-23727-23729

2. Balakrishnan P., Bharthvajan R.,A study on human resource planning in hospitals in Chennai City,2014,International Journal of Applied Engineering Research,V-9,I-22,P-7503-7507

3. Priyadarsini P., Bharthvajan R.,Role of emotional intelligence training programme in reducing the stress of the nurses,2014,International Journal of Applied Engineering Research,V-9,I-22,P-7411-7421

4. Kerinab Beenu G., Bharthvajan R.,Empirical analysis on the cosmetic buying behavior of young women in South India,2014,International Journal of Applied Engineering Research,V-9,I-22,P-7361-7366

5. Balakrishnan P., Bharthvajan R.,Whistling in the wind,2014,International Journal of Applied Engineering Research,V-9,I-22,P-7586-7593

6. Krishnan B., Peter M.,Health hazards of Indian Bpo employee-an alarming issue,2014,International Journal of Applied Engineering Research,V-9,I-22,P-7336-7341

7. Kerinab Beenu G.H., Peter M.,Role of insurance in economic development,2014,International Journal of Applied Engineering Research,V-9,I-22,P-7532-7539

8. Balakrishnan P., Peter M., Priyadarsini P.,Efficiency of safety measures for wellbeing of employees in manufacturing industry,2014,International Journal of Applied Engineering Research,V-9,I-22,P-7376-7382

9. Anbarasi M., Praveen Kumar S.,Online sales promotions of herbal products and its effectiveness towards tanisha.com,2019,Indian Journal of Public Health Research and Development,V-10,I-1,P-195-200

10. Anbarasi M., Praveen Kumar S.,Various online marketing and promotions strategies to improve the validation towards the organic products in the pharmaceutical sectors,2019,Indian Journal of Public Health Research and Development,V-10,I-1,P-263-269

11. Loganathan R., Praveen Kumar S.,Grievance handling a key factor for solving issues of employees in an organization,2014,International Journal of Applied Engineering Research,V-9,I-22,P-7483-7491

12. Loganathan R., Praveen Kumar S.,Study on preference of private labe brands in super and Hypermarkets, 2014,International Journal of Applied Engineering Research,V-9,I-22,P-7327-7335

13. Smitha M., Praveen Kumar S.,Understanding stress and its managementamong the nurses in Chennai city,2014,International Journal of Applied Engineering Research,V-9,I-22,P-7560-7565

14. Kerinab Beenu G.H., Praveen Kumar S.,A study on the investment behavior of Chennai investors in mutual fund schemes,2014,International Journal of Applied Engineering Research,V-9,I-22,P-7520-7525 
15. Loganathan R., Praveen Kumar S.,Retention strategies key for organizational productivity,2014,International Journal of Applied Engineering Research,V-9,I-22,P-7443-7447

16. Pavithra J., Ganesan M., Brindha G.,State wise analysis of microfinance sector in India,2016,International Journal of Pharmacy and Technology,V-8,I-4,P-23417-23432

17. Pavithra J., Ganesan M.,A comparative study on microfinance in India and abroad,2016,International Journal of Applied Business and Economic Research,V-14,I-8,P-5471-5476

18. Pavithra J., Ganesan M.,A study on awareness and impact of micro-financial schemes,2016,International Journal of Applied Business and Economic Research,V-14,I-8,P-5449-5460

19. Senthilmurugan P., Pavithra J.,Consumer preference towards organised retailing with reference to Big Bazaar,2014,International Journal of Applied Engineering Research,V-9,I-22,P-7469-7475

20. Senthilmurugan P., Pavithra J.,Implication of social media marketing in growing healthcare industry,2014,International Journal of Applied Engineering Research,V-9,I-22,P-7448-7456

21. Loganathan R., Pavithra J.,Consumer perception towards private label brand over other brands in super markets and hypermarkets,2014,International Journal of Applied Engineering Research,V-9,I-22,P-7355-7360

22. Kerinab Beenu G., Pavithra J.,Tradeâe"off between liquidity and profitability in logistics industry,2014,International Journal of Applied Engineering Research, V-9,I-22,P-7398-7401

23. Kerinab Beenu G., Pavithra J.,A study on the prospective consumerâ€ $€^{\mathbf{T M}_{\mathbf{S}}}$ perception towards utility cars in Chennai city,2014,International Journal of Applied Engineering Research,V-9,I-22,P-7526-7531

24. Pavithra J., Dilli Babu P., Ambuli T.V.,A study on budgetary control at Maruti Service Masters, Chennai,2014,International Journal of Applied Business and Economic Research,V-12,I-2,P-151-161

25. Pavithra J., Dilli Babu P., Ambuli T.V.,A study on customer satisfaction of retro Garments Pvt Ltd, Chennai,2014,International Journal of Applied Business and Economic Research,V-12,I-2,P-381-391

26. Kerinab Beenu G.H., Pavithra J., Senthilmurugan P.,A study on the influence of promotional activities for TATA ARIA among consumers in Chennai,2014,International Journal of Applied Engineering Research,V-9,I-22,P-7572-7578

27. Vijayaragavan S.P.,An investigative expert that's general FBG sensors,International Journal of Mechanical Engineering and Technology,V-8,I-8,PP-1500-1505,Y-2017

28. Vijayaragavan S.P.,Equalization routing protocol for Wi-Fi sensor strategy,International Journal of Mechanical Engineering and Technology,V-8,I-8,PP-1662-1666,Y-2017

29. Karthik B., Kiran Kumar T.V.U., Vijayaragavan P., Bharath Kumaran E.,Design of a digital PLL using $0.35 \hat{1} 1 / 4 \mathrm{~m}$ CMOS technology,Middle East Journal of Scientific Research,V-18,I-12,PP-1803-1806,Y-2013

30. Kanniga E., Selvaramarathnam K., Sundararajan M.,Kandigital bike operating system,Middle - East Journal of Scientific Research,V

31. Jasmin M., Vigneshwaran T., Beulah Hemalatha S.,Design of power aware on chip embedded memory based FSM encoding in FPGA,International Journal of Applied Engineering Research,V-10,I-2,PP-4487-4496,Y-2015

32. Jasmin M.,Optimization techniques for low power VLSI circuits,Middle East Journal of Scientific Research,V-20,I-9,PP-1082-1087,Y-2014

33. Jasmin M., Vigneswaran T.,Fuzzy controller for error control of on - Chip communication,2017 International Conference on Algorithms, Methodology, Models and Applications in Emerging Technologies, ICAMMAET 2017,V-2017-January,I-,PP-1-5,Y-2017

\section{AUTHORS PROFILE}

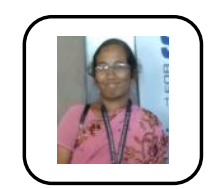

J.Pavithra Assistant Professor ,Department of MBA, Bharath Institute of Higher Education and Research, Tamilnadu, India

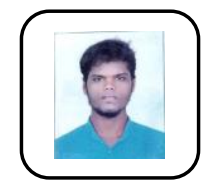

Ajith Student ,Department of MBA, Bharath Institute of Higher Education and Research, Tamilnadu, India.

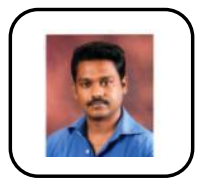

Dr.A.Kamal Associate Professor ,Department of EEE, Bharath Institute of Higher Education and Research, Tamilnadu, India 